\title{
ISHA GAMLATH
}

University of Kelaniya, Sri Lanka

\section{THE TRAINING OF PORPHYRY'S 'ATHLETE': THE ASCETIC PHILOSOPHER IN ON THE ABSTINENCE FROM EATING FLESH}

\begin{abstract}
Gamlath Isha, The Training of Porphyry's 'Athlete': The Ascetic Philosopher in On the Abstinence from Eating Flesh.

The image of the historical athlete who enters the ancient Greek stadium is a perfect medium for clarifying the conceptual philosopher's liberation from material bonds and ascent to the higher causal order in Porphyry's On the Abstinence from Eating Flesh. The image is emphasized when Porphyry prescribes the practice of vegetarianism and immaterial sacrifice for the conceptual philosopher's preparation for the specific 'contest' of freeing from material concerns such as food and sacrifice and eventual transformation in to the as the priest of the Highest God.
\end{abstract}

Keywords: Porphyry; ascetic philosopher; athletic training; contests; frugality; vegetarianism; immaterial sacrifice.

THE ATHLETIC IDEAL

Out of the mass of information on athletics and athletic training in ancient Greece it turns out that athletics formed a central component of the civic life. ${ }^{2}$ The athlete in ancient Greek culture, specifically of the 5th century BC, was committed to fulfill the social obligation of participation in the numerous athletic contests. Sources locate athletics among two other disciplines of traditional elite male education in Athens of the Classical period, music and grammar (Plato, Alcibiades, 118c-d; Laches, 184e). The athletic ideal, as a specific social discipline contributing to the cultivation of arête in ancient Greek culture through training, has been described as reflecting affinity with askesis, an initially ritualistic and later intellectual development. The idea has already been the focus of many ancient writers before Porphyry such as Socrates, the Cynics, medical

\footnotetext{
${ }^{1}$ My sincere thanks go to the anonymous reviewer whose insightful suggestions and assistance are very much appreciated and Professors Magdalena Stuligrosz and Maria MarcinkowskaRosół of Adam Mickiewicz University in Poznań, Poland. I dedicate this article to my beloved father, Prof. Sucharita Gamlath on his $5^{\text {th }}$ death anniversary.
}

${ }^{2}$ Pritchard 2013: 84-138. 
writers, Marcus Aurelius and Plotinus. The historical Greek athlete who labors in the arena (athlētếs) for perfection of athletic prowess (agon) exemplifies the pain (ponos) and struggle (agon) which formed a central part of his pursuit of personal excellence (arete). A late but fairly reliable source on athletics, Philostratus elaborates on the pain experienced by early athletes while training:

By gymnastike the men of the past meant any exercise whatsoever. Some trained themselves by carrying weights which were hard to lift, some by competing for speed with horses and hares, others by straightening or bending thick pieces of wrought iron, while some yoked themselves with powerful, waggon-drawing oxen, and others wrestled bulls and even lions by the throat. That is what training involved for men like Polymestor and Glaucus and Alesias and Poulydamas from Scotussa. Tisandrus the boxer from Naxos used to swim around the headlands of the island and his arms carried him great distances through the sea, training both his body and themselves. They washed in rivers and springs, and they trained themselves to lie on the ground, some of them stretched out on skins, others harvesting their beds from the meadows. $(\text { Gymn. } 43)^{3}$

In the philosophical discussions of the Hellenistic period and Late Antiquity, athletic training is discussed as perfect medium for the fulfillment of the philosopher's specific return, the return of the soul to its pristine self. Athletic training, described as a medium applicable for the soul's return to its pristine self, is an endeavor which stretches as far back as Plato, who admits that the soul's true nature is revealed once it is stripped of the body:

All that is in the soul is evident after it has been stripped naked of the body both things that are natural to it and things that have happened to it things that the person came to have in his soul as a result of his pursuit of each objective. (Gorgias, 524d-e)

The philosopher's exertion to fulfill this return has been equated this return, in the Greek intellectual tradition, notably in the post-Aristotelian phase of Greek philosophy - a phase specifically rich in defending the notion of the soul's return where freedom from material constraints which forms the main core of its teachings - to that of the athlete in the stadium. The dominant idea that pervades Greek thought, specifically of the period between the last centuries before the common era and the early centuries of common era, is that rejection of individuality and passions assists to view things from a perspective of universality and objectivity. The endeavor was often considered as associating the athletic ideal in specific philosophical circles such as the Stoics and the Epicureans. The change of appreciation of a beautiful and supple male body is most visible in the philosophy of the Stoics who claim that while one chooses and pursues certain goods, success depends not on our achieving them, but on our choosing and pursuing them in a rational way. As such, the Stoics define the

${ }^{3}$ Philostratus 2014. 
philosopher's goal as that of an "archer, who has a target that he means to hit, but whose goal is not that an arrow should be in the target, but that he should aim and shoot well with respect to the target" (Cicero, De Finibus III.22-5, V.20-1). The predominant goal of Stoic moral philosophy is to help train the "would-be honorable and good man" (Epictetus, Discourses, 111.2.1). The training motif, for the Stoics, is an expression applied to freeing the soul from material concerns (Discourses, 3). Discipline is what is expected of the philosopher who labors for his return. Training is a requirement of the philosopher's progress, the undertaking of which is similar to the trainer's instruction to the athlete: "Wrestle again till you have made yourself strong' - that's an instruction from the athletic trainer to a boy who has fallen - but used as a metaphor for philosophical progress" (Discourses, 4.9.15). The motif of training continues in to the life style patterns among philosophical circles such as the Cynic school. Emphasis in the Cynic school becomes more marked on features associating behavioral patterns such as simplicity, frugality, freedom from social restraint, self-sufficiency, endurance, self-control, homelessness and above all voluntary poverty:

This was a basic part of the thorough going training which sought to insure the Cynic to a haphazard fortune. Such ascesis in the wider sense included what we may recognize as ascetic practice in the narrower sense of a training in character through physical hardship and renunciation. A fundamental element of this training was voluntary poverty. ${ }^{4}$

Diogenes is represented as an individual who enjoys simplicity as is obvious in his frugal lifestyle. He enjoys solitude as he has no fixed abode. He has few personal belongings. He used to go barefoot through the snow (Lives, 6) just like Socrates, who as Alcibiades says, walked bare foot on snow in an old light coat (Symposium, 220b-d). He was "houseless and citiless, a piteous exile from his dear native land; a wandering beggar scraping a pittance poor from day to day" (6). He stressed the importance of exercise - that of the mind and the body. ${ }^{5}$

${ }^{4}$ Finn Op 2009: 19; The Cynic parrësia boldness of speech was thus a mode of personal training (On the Cynic, parresia, and asceticism, see Vaage 1992: 25-39).

5 "He used to say that there were two kinds of exercise: that namely, of the mind and that of the body; and that the latter of these created in the mind such quick and agile phantasies at the time of its performance, as very much facilitated the practice of virtue; but that one was imperfect without the other, since the health and vigor necessary for the practice of what is good, depend equally on both the mind and body. And he used to allege as proofs of this and of the ease which practice imparts to acts of virtue, that people could see that in the case of mere common working trades and other employments of that kind, the artisans arrived at no inconsiderable accuracy by constant practice; and that any one may see how much one flute player or one wrestler is superior to another, by his own continued practice. And that if these men transferred the same training to their minds they would not labor in a profitless or imperfect manner. He used to say, also, that there was nothing whatever in life which could be brought to perfection without practice and that that alone was able to overcome every obstacle; that therefore as we ought to repudiate all useless toils 
The athletic motif signals a tradition of thought which particularly defends the soul's effort to move from corporeal bondage and return to its previous location. Plotinus enlightens his listeners on asceticism. ${ }^{6} \mathrm{He}$ also discusses the use of athletic metaphor in the philosopher's ascent to the causal order (Enneads, 1.8.14). ${ }^{7}$ Marcus Aurelius (Meditations, 3.8.6.20). and Plotinus (1.4.8) specially speaks of the sage as "megas athletes". ${ }^{8}$ This enterprise, in Pierre Hadot's opinion, requires the application of "spiritual exercises":

Each in its own way, all schools believed in the freedom of the will, thanks to which man has the possibility to modify, improve, and realize himself. Underlying this conviction is the parallelism between physical and spiritual exercises: just as, by dint of repeated physical exercises, athletes give new form and strength to their bodies, so the philosopher develops his strength of soul, modifies his inner climate, transforms his vision of the world, and, finally, his entire being. The analogy seems all the more self-evident in that the gymnasion, the place where physical exercises were practiced, was the same place where philosophy lessons were given; in other words, it was also the place for training in spiritual gymnastics. ${ }^{9}$

Hadot's clarification of the particularly fertile venue of "gymnasium" of the soul for "training in spiritual gymnastics" stresses for facilitates the philosopher's endeavor to 'return' to his original status. As a counterpart of the physical gymnasium where the Greek athlete strove for athletic success, the "gymnasium" of the philosopher's soul is the best venue for producing the specific category - the philosopher whose specific labor is similar to the athlete's preparation for athletic events and whose ultimate fulfillment of the return to that of the athlete's Olympic victory.

The athletic motif begins to be treated, by around the late $3^{\text {rd }}$ and $4^{\text {th }}$ centuries $\mathrm{AD}$ in relation to the Christian ascetic's commitment to maintain simplicity and frugality. The Christian corpus of literature of the $4^{\text {th }}$ and $5^{\text {th }}$ centuries AD is rich in material referring to askesis as a specific discipline for the formation of the recluse who is often defined as Christ's soldier and athlete. As soldier and athlete the Christian recluse was supposed to combat his warring sensory instincts. Hostility towards the body, especially sexual impulse, collectively known as encratism, becomes noticeable by approximately the $2^{\text {nd }}$ century AD that it ultimately aimed at the reconstruction of a new Christian personality. ${ }^{10}$ The metaphors soldier and athlete, were expressions of the Christian ascetic's

and to apply ourselves to useful labors and to live happily, we are only unhappy in consequence of most exceeding folly" (5).

${ }^{6}$ Dombrowski 1987: 703-704.

${ }^{7}$ Dombrowski 1987: 706-707.

${ }^{8}$ Dombrowski 1987: 701-712.

${ }^{9}$ Hadot 1985: 102.

${ }^{10}$ Krueger 1999: 217. This attitude to hostility towards the body is not a specifically Christian phenomenon but a cultural one (Dodds 1968: 29-36). 
severe commitment to combat such spaces of material pleasure as food, drink, accommodation and sex. ${ }^{11}$

Athletic training in this sense, is a special kind of training as it is interwoven to a specific way of life - a way of life which in Porphyry's estimation befits nobody else but the philosopher:

In the first place, therefore it must be known that my discourse does not bring with it an exhortation to every description of men. For it is not directed to those who are occupied in sordid mechanical arts, nor to those who are engaged in athletic exercises, neither to soldiers, nor sailors, nor rhetoricians, nor to those who lead an active life. I write to the man who considers what he is, where he came and whither he ought to tend and who in what pertains to nutriment and other necessary concerns is different from those who propose to themselves other kinds of life for none but such as these I direct my discourse. (Abst.1.27) ${ }^{12}$

\section{THE “OLYMPIA OF THE SOUL”: STRIPPING MATERIAL CONSTRAINTS}

Porphyry begins his discussion of the ascetic philosopher's conceptual training by referring to the training of the naked athlete, a familiar figure in Greek culture. The nudity of the athlete reveals significant social realities. ${ }^{13}$ Nude exercise signified "strength," "courage," "prestige," and very specially "inclusion in the male citizen body." 14 Porphyry elaborates on the standard motif of the naked Greek athlete in an interesting way, with an emphasis on the notion of stripping away as something conspicuous for the training of the ascetic philosopher in On the Abstinence from Eating Flesh. Porphyry does not specifically exploit the impact of the versatility of athletic training in antiquity except when he uses the athletic metaphor for his immediate concern - to lure his companion, Firmus Castritius, to resume a vegetarian life style as he had begun to continue consumption of a meat (Abst. 1.1-3). Porphyry explains in fairly encouraging tones, to Firmus Castricius, of the importance of stripping material bonds. Porphyry perceives that the historical athlete's removal of attire is a symbolic expression of the ascetic philosopher's specific removal which is a renunciation

${ }^{11}$ On the image of the ascetic as atheltica Christi cf: Bazell (1997: 76 n.7); The metaphors, widespread in most Christian groups in the eastern Mediterranean, as far as Syria and Egypt, envisions the presence of a thriving ascetic community whose labor was devoted to further areas such as manual labor. Syriac and Egyptian traditions, in the early centuries before and after their encounters with the Roman Empire, is rich in material of specific ascetics whose discipline reflects the type of life that he had chosen for himself. The ascetic could often be working oneself in response for the demands of others such as manipulation of sorcery (Brown 1971: 80-101).

${ }^{12}$ Porphyry 2008. On the Abstinence from eating flesh, hereafter Abst.

${ }^{13}$ In Sparta nudity was a key means of building unity among the members of the phalanx. It also made competition among themselves for physical fitness as its primary function was effectiveness in military activity (Christessen 2014: 211-235).

${ }^{14}$ Bonfante 1989: 543-570. 
from material pleasures. In Porphyry's estimation, athletic training is equivalent to the specific "training' for the ultimate perfection of the "Olympia of the soul":

We must therefore divest ourselves of our manifold garments, both of this visible and fleshly vestment and of those with which we are internally clothed and which are proximate to our cutaneous habiliments and we must enter the stadium naked and unclothed, striving for ( the most glorious of all prizes) the Olympia of the soul. The first thing however and without which we cannot contend is to divest ourselves of our garments. (Abst.1.31)

Porphyry informs Firmus Castricius that the philosopher's achievement of the "Olympia of the soul," can only be fulfilled by a specific philosophical endeavor which permits the "return" of the embodied soul to its rightful abode, the higher causal order:

Hence he who wishes to return to his proper kindred and associates should not only with alacrity begin the journey but in order that he may be properly received should mediate how he may divert himself of everything of a foreign nature which has assumed and should recall to his memory such things as he has forgotten and without which he cannot be admitted by his kindred and friends. (Abst. 1.30)

What is noticeable is that the "return" to the ascetic philosopher's proper kindred involves laborious athletic endurance which will facilitate the "journey" and make him "divert" his attention from associating everything of a "foreign nature." It is a profound commitment as it involves to divest, from not clothes, as in the case of the traditional athlete but from commitment to sensory concerns. The "journey" to the soul's rightful abode, the noetic region, is described as an athletic "contest." The athletic metaphor seems to be important for Porphyry as it fulfilled the accomplishment of the particular goal of the ascetic philosopher, union with the divine. Stripping, Porphyry considers, is a strong symbolic expression of self-denial which ensures the soul's freedom from material bonds. ${ }^{15}$ The image of the Greek athlete who enters the stadium, stripping his clothes, is for Porphyry a pertinent metaphor to describe the importance of the soul's removal of material bonds and eventual freedom from its lamentable misery of corporeal stagnation:

Porphyry understood the goal of philosophy as that contemplation in the soul of divine truth which was also an act of union with the divine. The athletic metaphor of his appeal to the dedicatee of On Abstinence, and through him to its readership, glorified both the goal and the philosopher who attained it; the image bestowed on the latter the prestige of victory in these most famous of all Greek games, and something of the victor's numinous power. ${ }^{16}$

\footnotetext{
${ }^{15}$ Purification of the soul as taking away clothes reflects the preparation for initiation in to mysteries (Plotinus, Enneades, 1.6.7).

${ }^{16}$ Finn Op 2009: 9.
} 
The historical reality of the "prestige of victory," in Olympic games, is viewed by Porphyry as one that embodies "numinous power." This, Porphyry notices, is the fruit of a more specific type of training than that of the historical athlete and he therefore attempts to ally the conceptual limits of training with contemporary philosophical culture, which already retained the Platonic theory of the soul discarding material bonds, in order to create a metaphor for the training of the ascetic philosopher:

The metaphor further located this goal as the fruit of a strict training (in Greek askesis) comparable to the diet, sexual abstinence, and exercises of the naked Olympic athlete. It was an apt metaphor in as much as the philosopher had to divest his mind of the multiple concerns and passions which distracted it through its relationship to the body; such concentration could easily be envisaged as a stripping naked of the self, because Plato had long since characterized the body as clothing worn by the soul. The figure was all the more apt in so far as the disciplined training which Porphyry thought would facilitate contemplation involved, amongst other things, a daily practice of ascetic abstention in matters of diet, sexual activity, wealth, and wider social intercourse, all elements in a thoroughgoing detachment from the material and mortal. ${ }^{17}$

\section{"SEVERE CONTESTS"}

The historical athlete is at times represented as one undergoing severe renunciation. This "renunciation" is mentioned in Philostratus who in the $3^{\text {rd }}$ century AD writes that abstinence was imposed on ancient athletes during athletic exercises and that a ban may have been imposed on beer and sex:

Athletes who are heavy drinkers can be detected by an oversized stomach and blood which is too lively and moistness in the flank and the knee. Those who come to the gymnasium straight after sex are exposed by a greater number of indicators when they train, for their strength is diminished and they are short of breath and lack daring in their attacks, and they fade in color in response to exertion, and they can be detected by signs of that sort; and when they strip, their hollow collar-bones give them away, their loose hips, the conspicuous outline of their ribs, and the coldness of their blood. These athletes, even if we dedicated ourselves to them, would have no chance of being crowned in any contest. The part beneath the eyes is weak, the beating of their hearts is weak, their perspiration is weak, their sleep, which controls digestion, is weak, and their eyes glance around in a wandering fashion and indicate their awareness of being loved. (Gymn. 48) $)^{18}$

\footnotetext{
${ }^{17}$ Finn Op 2009: 9-10.

${ }^{18}$ The tendency to treat the Greek athlete as representing an "ascetic" lifestyle originated in late Antiquity:

"The athlete was not an ascetic. Although both life styles were based on persistent training and self-control taken to unhealthy extreme they aimed at opposite effects. The perfect athlete abstained from certain physical pleasures in order to become a victor in physical contests while the ascetic subdued all kinds of lusts in order to win the metaphysical contest that was life" (Remijsen 2015: 274).
} 
Porphyry seems to be influenced by this trend and seems to apply its fruits to his discussion in Abst. Porphyry writes that the ascetic philosopher's "return" to his due destination is by no means a simple enterprise. It demands serious, constant and prolonged attention on removal of material constraints. The specific training of the ascetic philosopher demands the elimination of passions:

And this being the case ought we not to sustain everything, though of the most afflictive nature with equanimity, for the sake of being purified from internal disease, since our contest is for immortality, and an association with divinity, from which we are prevented through an association with the body? (Abst. 1.56)

The way of life of the philsopher indicates a specific type of training which resembles the training of the athlete. Yet it is an altogether different training - a training which is in reality a lifestyle pattern embodying a severe physical exertion for limiting material concerns. It is a training which evolves from a way of living principally founded on elimination of passions. The distinctiveness of elimination of passions, in Porphyry's description, is so strong as it brings to light the notion of an athlete's strenuous efforts in an athletic contest:

To be purified from all these is most difficult and requires a great contest and we must bestow much labor both by night and by day to be liberated from an attention to them and this because we are necessarily complicated with sense. Whence also as much as possible, we should withdraw from those places in which we may though unwillingly meet with this hostile crowd. From experience also we should avoid a contest with it, and even a victory over it and the want of exercise from inexperience. (Abst. 1.35)

The "contest" is "great" and "most difficult" as it involves strenuous "labor" for discarding sensory pleasures. While the masses seek ways to collect more and more material assets, the ascetic philosopher will find ways to reduce them. This reduction, as Porphyry perceives, is metaphorically the ascetic philosopher's "contest." It is not the kind of athletic contest known to the Greeks. There is no joy of celebration of physical prowess. It is a "contest" of a different kind. It is expected to reduce material concerns. It is a truly different "contest" as it represents a total renunciation from bondage to passions.

\section{SPECIFIC CONTESTS: PRACTICE OF FRUGALITY AND VEGETARIANISM}

Porphyry suggests that the ascetic philosopher's training could be supplemented by a simple life style, specifically involving "frugality":

The pleasure however which is produced through luxury does not even approach to that which is experienced by him who lives with frugality. For such a one has great pleasure in thinking how little he requires. For luxury, astonishment about venereal occupations and ambition bout external concerns, being take away, what remaining use can there be idle wealth which will 
be of no advantage to us whatever but will only become a burden no otherwise than repletion? While on the other hand the pleasure arising from frugality is genuine and pure.'(1.54). Forms of impurity are many among which are sepulchers, impious men, menstrual purgations, venereal congress, base and mournful spectacles, auditions that excite the passions. (2.50)

Historically, the notion of "frugality" stretches to food consumption habits in Sparta :

The Spartans had a reputation for an abstemious lifestyle, but this reputation should not be taken to mean that they consumed amounts of food at the lower end of the range for Greek norms, for, even besieged, they consumed more food than the ordinary Greek soldier. Rather, their repute for moderation was justified by the absence of exotic foods from their mess (Hdt. 9.82; Athen. 4.138D; Plut. Lyc. 12.13), and by the peer pressure exerted against overeating by mess members. (Xen. Resp. Lac. 5.2-7; Plut. Lyc. 12.14) ${ }^{19}$

Porphyry makes it clear that within the philosophical endeavor of approaching the noetic realm the ascetic philosopher ought to discard the desire for "luxurious food." Porphyry's ascetic philosopher is described as abstaining from luxuries, particularly from the luxury of a diet of meat:

The contemplative philosopher, however will invariably adopt a slender diet. For he knows the particulars in which his bond consists, so that he is not capable of desiring luxuries. Hence, being delighted with simple food, he will not seek for animal nutriment as if he was not satisfied with a vegetable diet. (Abst. 1.56)

Historically, the introduction of vegetarianism to Greek culture was clearly a practice outside the bonds of normal practice which involved meat consumption and thus reveals a clear social (and religious) identity:

A rejection of meat was, in effect, a gross act of impiety. Ancient religious ritual was a communal act in which men sought guidance or protection from the gods to ensure the continued survival and prosperity of the body politic (or at least protection from adversity and manifestations of divine malevolence). Dismissal of its significant ritual act (animal sacrifice) might be interpreted as a renunciation of the gods, even a betrayal of the whole community. ${ }^{20}$

The ascetic philosopher who resumes this identity submits to a way of living which involves total abstinence from meat, a vital measure to fulfill his conceptual intention - eventual ascent to the highest source of divine wisdom. This diet is particularly important as it reveals the attention bestowed on the idea of the philosopher's health. ${ }^{21}$ It seems that Porphyry was influenced by the historical

\footnotetext{
${ }^{19}$ Figuera 1984: 91. See also on Spartan austerity: Holladay 1977: 111-126.

${ }^{20}$ Beer 2010: 29; Attitudes to food, however, formed a major part in religious discussions of late Antiquity (Purcell 2003: 330).

${ }^{21}$ The philosopher's health has been discussed as the health of the "spiritual athlete" (Clark 2005: 227).
} 
developments associated with ancient conceptions of diet. Archaic culture, prior to the emergence of such medical personalities as Alcmaeon and Hippocrates of the, is free from an explicit reference to the notion of the nutritious value of 'diet' as forming a part of the ancient view of health. What was originally known as health in antiquity was a condition of "absence of disease and illness." 22 Early Greek literature, for instance, Homer and Hesiod, do not specifically mention of the importance of dietetics. ${ }^{23}$ By the Classical period, with the emergence of theoretical debates on the character of health, in the form a large corpus of Hippocratic treatises attesting a rich dietetic terminology, explicit dietetic concerns and more specifically the circulation of Pythagorean doctrines, importance was beginning to be attached to health, medicine, dietetics within athletic training. ${ }^{24}$ The hypothesis of the relationship between athletics and the medical character of dietetics is, however, challenged:

First while medical dietetics aims at health and its preservation the goal of the athletic training is first of all to achieve the highest possible performance often at the cost of health and this explains the more or less drastic prescriptions attested for the athletic version of dietetics. And second athletic training focuses mainly on athletes, a particular minority enjoying an elite social status and demanding a special care from professional trainers and specialized physicians. ${ }^{25}$

Dietetics is introduced not specifically for health but for the "highest possible performance" through which the athlete demonstrates his skill. The custom in the Archaic period was "not to maintain health rather than to improve combat skills, to train youngsters for their military duties or to win prestige in athletic competitions." ${ }^{26}$ The practice of dietetics develops with importance attached to the development of medicine in Greece. Originally connected with such concepts as Asclepius, Hygeia and Hero Iatros, then, health as healing, begins to be associated by the $5^{\text {th }}$ century $\mathrm{BC}$ with emerging theoretical discussions of health, new therapeutic techniques and the new medical developments of this period which did associate Greek temple medicine. ${ }^{27}$

${ }^{22}$ Hynek 2015: 17.

${ }^{23}$ The exact dates of the emergence of dietetics in Greek culture is conjectural: "Although dietetics appeared to be well developed at the end of the fifth century $\mathrm{BC}$, the ancients commonly regarded it as a sixth- or fifth- century $\mathrm{BC}$ invention. The ancients had noted the absence of regimen in Homer, where only surgery and application of (external) medicaments are described, and concluded that dietetics did not exist at the time of the epic poet, but had been invented later. There was, however, considerable debate on who was the inventor: some considered Pythagoras of Samos deserved the title, for some it was Herodicus of Selymbria, and for others it was the physician Hippocrates of Cos" (Totelin 2009: 133).

${ }^{24}$ Hynek 2015: 29-36; on the Crotonian-Pythagorean roots of dietetics, see Hynek (2015: 24 n.69); for a more coherent description, Zhmud (2012: 347-364).

${ }^{25}$ Hynek 2015: 99-100.

${ }^{26}$ Hynek 2015: 16.

${ }^{27}$ Hynek 2015: 18 n.36. 
Motivated by the tradition of medical thought and practice Porphyry prescribes a vegetarian diet for the ascetic philosopher in Abst. The ascetic philosopher will therefore consume a vegetarian diet for a profound purpose. He is aware of his "bond" - the bond with the divine which he trains himself to revive. In this revival he abstains from the luxury lifestyle that could divert his "bond." The luxury lifestyle includes the luxury of a meat diet, for which the masses have absolutely no restraint. The masses are interpreted as voraciously feeding on flesh (1.53). Porphyry does not find fault in the consumption of meat by such personalities as athletes, soldiers and those engaged in menial tasks (2.4). But Porphyry certainly prescribes a vegetarian diet for the ascetic philosopher for which Porphyry's explanations range as health $(1.45,52-53)$, simplicity in preparation $(1.46-47,49,51)$, ease in procurement $(1.47-49,51$, $56)$, absence of pain to living beings (1.49-50), light nutriment $(1.38,45-46$, $50)$, frugality (1.47-51, 54, 3.26), moderation (1.54), self-sufficiency (1.37, $46-47,49,54)$, ease of digestion (1.45), elimination of satiety $(1.46,54)$, elimination of variation $(1.51,55-56)$, elimination of luxury $(1.46-47,49,51$, $54-56,3.18$ ), attainment (or maintenance of peace (1.47) and freedom from defilement (4.20).

\section{IMMATERIAL SACRIFICE}

Porphyry proposes sacrifice as a vital component of the ascetic philosopher's conceptual 'training'. The ascetic philosopher is prescribed the practice of sacrifice as it assists him to reach his ultimate goal - the ascent to his rightful abode. Sacrifice, it appears, is a key means of fulfilling the 'contest' for immortality and the "competition for the Olympia of the soul." The sacrifice prescribed for ascetic philosopher is of a specific type. It does not agree with the common pagan practice of blood sacrifice (2.9-12). ${ }^{28}$ Nor does it particularly include the primitive bloodless sacrifice (2.5-6). ${ }^{29}$ Sacrifice of bloodless substance is usually addressed in literary sources as "theoxenia" or "trapezōmata":

Besides being meat, trapezōmata were sometimes cakes and other vegetal offerings. Such tables were for poorer gods, like Hecate and Hermes, whose pillars held bits of food. (In contrast, Aristophanes's Plutus describes two tables for Asclepius one for fowl and one for cakes

${ }^{28}$ Despite its predominant position it has been noted as "disordering of kinship relations" (Townsend 2003: 221); thus, also the Porphyry's apparent "demonization of blood sacrifice" (Marx-Wolf 2010: 496). Sacrifice of bloodless substance is adequately addressed in the form of theoxenia. On the theoxenia cf: Ekroth (2008: 98); on the practice and terminology (97 n.57); the practice is a 'complex matter' (101; cf $101 \mathrm{n} .75-79)$; on the use of offering cakes, se Kearns (2011: 90, 89-110); Jameson (1994, 35; also 36 n.1).

${ }^{29}$ Bloodless sacrifice was a dominant ritual in late antiquity (Nilsson 1945: 63-69; Clark 1999: 112-132; Fergusson 1980: 1151-1189; Eckhardt 2014: 255-273). 
and figs.) The same was true of theoxenia, especially for the Dioskouroi. In Athens, where the Dioskouroi received hospitality at the public hearth, the two gods received cheese, cakes, olives, and leeks, and no meat. ${ }^{30}$

Although bloodless sacrifice is of special worth for Porphyry's representation of the ascetic philosopher, he refers to the specific type of sacrifice which ought to be offered to specific entities. In this he displays his absorption of the Platonic theory of the divine hierarchy which he "has correlated with a hierarchy of sacrifice." 31 This absorption encompasses a specific principle of "correspondence":

Porphyry assumes a correspondence between sacrifice ritual and the structure of the cosmos; his objection to animal sacrifice is that by its very nature it establishes a connection between the person who performs it and a particular segment of the universe. ${ }^{32}$

The "correspondence" is further clarified when Porphyry asserts that blood sacrifice is reserved for daemons, the lowest entity in the hierarchy of the noetic universe:

These are they that rejoice in libation and the savor of sacrifices, through which their pneumatic vehicle is fattened; nor for this vehicle lives through vapors and exhalations; and the life of it is various through various exhalations. It is likewise corroborated by the savor of blood and flesh. (Abst. 2.42) $)^{33}$

\section{There are apparently two types of daemons as expressed in Porphyry:}

The portrait of daemons painted by Porphyry in On Abstinence is thoroughly consistent with the daemonologies of earlier Middle Platonist thinkers like Plutarch, though the sacrificial implications were obviously more pronounced in the later philosopher, thus fulfilling a central role within his overall defense of abstinence from meat. Two classes of daemons, beneficent and maleficent, inhabited the theological and meta- physical space between the divine and human. While the good daemons fostered balance and reason with respect to the material world, always directing human souls beyond the material to the divine, the bad daemons had thrown themselves with reckless abandon into all things physical, especially the bubbling fat and savory smoke of roasting meat. ${ }^{34}$

\footnotetext{
${ }^{30}$ Naiden 2013: 59-60. Plutus, 672-681.

${ }^{31}$ Rives 2003: 188.

${ }^{32}$ Rives 2003: 189.

${ }^{33}$ On daemons as "fat-loving," see Clark $(2001: 35,44)$. Clark makes some fascinating conclusions after acknowledging that "food in relation to soul is the connecting thread of Porphyry's extraordinarily wide-ranging discussion" (42); A 'fattened-heart' damages Augustine's understanding of God as a fattened irrational soul and body do in Porphyry's treatise (49); Fat is a philosophic issue (42-4). Plotinus had already written on the purification of the soul with connection to gluttony and even the smoke or the odor of meat or fat using the term 'gastrimargia' or 'gluttony', which makes the soul 'heavy' and 'fat' (Enneades,3.6.5.22-29; 5.5.11.11-16).

${ }^{34}$ Johnson 2013: 86.
} 
While daemons demand and enjoy blood sacrifice there are others who enjoy bloodless sacrifice, the progeny of the Highest God in the noetic universe $(2.34 ; 37)$. Bloodless offerings, the norm of the abstract context of the Golden Age, expands to Porphyry's prescription of immaterial sacrifice for the ascetic philosopher::

We however by no means contend with these, nor are we very desirous of being well instructed in a thing of this kind; but imitating holy and ancient men, we offer to the Gods more than anything else the first-fruits of contemplation which they have imparted to us and by the use of which we become partakers of true salvation. $\left(\right.$ Abst. 2.35) ${ }^{35}$

Porphyry certainly does not condemn the act of sacrifice (of animals) or even human sacrifice $(2.12,56)$ unless it is absolutely necessary $(2.44)$. Violation of ancient custom could in some respect exemplify renunciation from socially accepted norms and so he does not condemn sacrifice as an initial step for salvation. The link between sacrifice and salvation was close in late antiquity:

Universal sacrifice thus maintained the pax deorum and became increasingly important as Diocletian's reign progressed. This view of sacrifice however was deeply troubling to many of the emperor's subjects who were concerned with personal salvation. Christians of course even those affiliated with the imperial court thought that traditional sacrifice threatened their salvation. And a number of philosophically-minded pagans also saw sacrifice as potentially polluting thus compromising their soul's progress toward immortality. ${ }^{36}$

Porphyry's effort is striking within the context of the Christian empire with Theodosius' (379-395 AD) prohibition of blood sacrifice despite of course the efforts of Julian. Civic cult means nothing for the ascetic philosopher whose worship of the Highest God is free from the ritualistic range of traditional pagan sacrifice. ${ }^{37}$ The ascetic philosopher is therefore instructed to worship not the traditional gods, who require material forms of worship such as bloodless sacrifice $(2.32,34-36$, $43,45,47,49,52-53,61) .{ }^{38} \mathrm{He}$ is instructed to worship and sacrifice to the Highest God, the highest in the Neoplatonic noetic universe, an abstract person, entirely self-sufficient and in no need of material sacrifice:

But the more excellent nature in the universe is entirely innoxious and through possessing a power which preserves and benefits all things is itself not in want of anything. We however through justice (when we exercise it) are innoxius towards all things but through being connected with mortality are indigent of things of a necessary nature. (Abst. 3.26)

\footnotetext{
${ }^{35}$ This type of offering is most explicitly connected to the well-being of the city: Johnson 2013:124.

${ }^{36}$ Digeser 2001: 520. See also: Digeser 2009: 81-92.

${ }^{37}$ Johnson 2013: 61.

38 "Notions of intellectual sacrifice promoted an ethic of withdrawal, even of spiritual separatism" (Johnson 2013: 126).
} 
The immaterial sacrifice - the sacrifice meant for the Neoplatonic Highest God - can be considered as consisting of the ascetic philosopher's conceptual training. It is an education to view the noetic universe differently - a difference far surpassing the union between the noetic entities and the human participant. The specific training which the ascetic philosopher undergoes is so vital for this venture that it ensures his freedom from material constraints; his stagnation amidst the masses who revel in sensory pleasures. Immaterial sacrifice, as consisting of the training of the ascetic philosopher transforms him into the priest of the Highest God (2.49-50). ${ }^{39}$ In this sense he is perceived as a fresh human category whose charisma is divine (1.54). He is, to be more precise, a domestic divinity (2.53). In the capacity of the priest of the Highest God the ascetic philosopher is expected continue specific practices among which the most predominant is maintenance of purity:

Father of all things excels in simplicity, purity and sufficiency to himself as being established far beyond all material representation by so much the more it is requisite that he who approaches to him should be in every respect pure and holy beginning from his body and ending internally and distributing to each of the parts and in short o everything which is present with him a purity adapted to the nature of each. (Abst. 1.57)

Purity is maintained through the approach to the Highest God. Purity is a vital component of the ascetic philosopher's conceptual training. It is a 'training' which demands specific requirements such as the practice of silence and the maintenance of a "pure soul" and "pure conceptions" (2.34). The best sacrifice for the Highest God is the possession of 'pure intellect' and an 'impassive soul' (2.61). This sacrifice helps the ascetic philosopher to notice his individual position in the noetic universe as his focus is on the ascent to the Highest God. The ascent demands a specific training which involves severe commitment, serious concentration, critical analysis. The worship of the Highest God is recommended to the acetic philosopher who ought to be a model for humanity (2.61). As a model for humanity the ascetic philosopher will educate the masses. The practice of vegetarianism and immaterial sacrifice will facilitate this education.

${ }^{39}$ On Porphyry's idea of the Highest God see Digeser (1998: 136): "Thus the Philosophy from Oracles defended the worship of the gods especially the one supreme God as the proper object of worship and adoration and it praised Jews for worshipping this one God. Porphyry's clear devotion to the one supreme God clearly did not annul his belief in the importance of the traditional forms of worship, for he saw no contradiction in asserting the necessity of sacrifice: while De Abstinentia does claim that the only offering worthy of a philosopher is a spiritual offering (1.28; 52-6: Eus.PE.4.10) it also defends sacrifices-not to the one supreme God but to lesser gods (2.33-4)." 


\section{CONCLUSION}

The specific type of training which Porphyry prescribes for the ascetic philosopher in On the Abstinence from Eating Flesh is expected to transform him into a specific human category who is exposed in the present study as a specific type of athlete. As an athlete the ascetic philosopher views the noetic universe in which he moved previously before his embodiment in human limits. More emphatically, as Porphyry conceptualizes, the endeavor of the ascetic philosopher who practices vegetarianism and an immaterial sacrifice, is different from that of the traditional Greek athlete. The athletic motif, which has been the focus of many writers before Porphyry, such as Socrates, the Cynics, medical writers, Marcus Aurelius and Plotinus begins to be treated in a different context, by approximately the late $3^{\text {rd }}$ and $4^{\text {th }}$ centuries $A D$, specifically in terms of the Christian ascetic's commitment to abstain from material pleasures. The attitude of hostility towards the body, which formed a significant role in Hellenic culture, philosophy as well as Gnosticism and Christianity, is addressed in Abst. with more consistency and concern when Porphyry perceives the historical image of the Greek athlete who strips his clothes as a relevant metaphor to describe the soul's freedom from material bonds and eventual ascent to the celestial region. Porphyry treats this image as providing adequate scope for the ascetic philosopher's "contest" - "contest for immortality." Porphyry uses the athletic motif to illustrate the centrality of the conceptual training of the ascetic philosopher whose "Olympia of the soul" is of specific importance. The specific "contest" which Porphyry prescribes for the ascetic philosopher is a specific mode of life involving submission to frugality in terms of a special diet and sacrifice for which he recommends vegetarian diet and immaterial sacrifice. The athletic motif is applied as a valid medium of expression for revealing the ascetic philosopher as a specific kind of athlete - an athlete who aims to achieve, not honour and success in the stadium, but the eventual ascent to the higher causal order. The intention of Porphyry's ascetic philosopher in Abst. is thus detached from that of the historical Greek athlete. More emphatically, Porphyry conceptualizes, in an altogether different setting, the training of the traditional Greek athlete when he prescribes vegetarianism and an immaterial sacrifice for the conceptual philosopher in Abst.

\section{BIBLIOGRAPHY}

\section{Primary sources}

Cicero. De Finibus. Ed. by H. Harris. 1931. Rackham.

Diogenes Laertius. Lives of Philosophers. Ed. by D. Hicks. 1947. London and New York. Epictetus. Discourses. Tr. by G. Long. 1904. New York.

Marcus Aurelius. The Meditations of Marcus Aurelius. Tr. by G. Long. 1909-1914. New York. 
Musonius Rufus, The Roman Socrates. Ed. by A. R. Bellinger. 1947. Yale.

Philostratus. Heroicus and Gymnasticus, Discourses 1 and 2. Ed. by J.P. Koenig and J. Rusten. 2014. Cambridge and London.

Plato. Complete Works. Ed. by J.M. Cooper. 1997. Cambridge.

Plotinus. Enneades. Ed. by P. Henry and H.R. Schwyzer. 1964-1982. Oxford.

Porphyry. On the Abstinence from Eating Flesh. Repr. by the Prometheus Trust. 2008. WestburyWiltshire.

\section{Secondary sources}

Bazell 1997: Bazell, D.M. 1997. "Strife among the Table-Fellows: Conflicting Attitudes of Early and Medieval Christians toward the Eating of Meat." Journal of the American Academy of Religion 65: 73-99.

Beer 2010: Beer, M. 2010. Taste or Taboo: Dietary Choices in Antiquity. Blackawton: Prospect Books.

Bonfante 1989: Bonfante, L.1989. "Nudity as a Costume in Classical Art." American Journal of Archeology 93: 543-570.

Brown 1971: Brown, P. 1971. "The Rise and Function of the Holy Man in Late Antiquity." The Journal of Roman Studies 61: 80-101.

Christessen 2014: Christessen, P. 2014. "Sport and Democratization in Ancient Greece.” In A Companion to Sport and Spectacle in Greek and Roman Antiquity. Ed. by P. Christessen and D.G. Kyle, 211-235. Oxford: Blackwell.

Clark 2001: Clark, G. 2001. "Fattening the Soul: Christian Asceticism and Porphyry on Abstinence in Ascetic." Gnostics, Liturgica, Orientalia, Studia Patristica 35: 41-51.

Clark 1999: Clark, G. 1999. "Translate in to Greek: Porphyry of Tyre on the New Barbarians." In Constructing Identities in Late Antiquity. Ed. by R. Miles, 112-132. London and New York: Routledge.

Clark 2005: Clark, G. 2005. "The health of the spiritual athlete.” In Health in Antiquity. Ed. by H. King, 216-229. Routledge: London and New York.

DePalma 2001: DePalma, D. 2001. "Porphyry, Lactantius and Paths to God." Studia Patristica 34: $521-528$.

Dodds 1968: Dodds, E.R. 1968. Pagan and Christian in an Age of Anxiety. Cambridge: Cambridge University Press.

Dombrowski 1987: Dombrowski, D. 1987. "Asceticism as Athletic Training in Plotinus." Aufstieg und Niedergang der römischen Welt 36: 701-712.

Eckhardt 2014: Eckhardt, B. 2014. "Bloodless Sacrifice: A Note on Greek Cultic Language in the Imperial Era." Greek, Roman and Byzantine Studies 54: 255-273.

Ekroth 2008: Ekroth, G. 2008. "Burnt, Cooked or Raw? Divine and Human Culinary Desires at Greek Animal Sacrifice Transformations." In Sacrificial Practices: From Antiquity to Modern Times. Ed. by E. Stavrianopoulou, A. Michaels, and C. Ambos, 87-112. Berlin: Lit Verlag.

Fergusson 1980: Fergusson, E. 1980. "Spiritual Sacrifice in Early Christianity and Its Environment." In Aufstieg und Niedergang der römischen Welt. Ed. by H. Temporini and W. Haase, 1151-1189. Berlin: de Gruyter.

Figuera 1984: Figuera, T.J. 1984. "Mess Contributions and Subsistence at Sparta." Transactions of the American Philological Association 114: 87-109.

Finn Op 2009: Finn Op, R. 2009. Asceticism in the Graeco-Roman World. Cambridge: Cambridge University Press.

Hadot 1985: Hadot, P. 1985. Philosophy as a Way of Life: Spiritual Exercises from Socrates to Foucault. Oxford: Blackwell.

Holladay 1977: Holladay, A.J. 1977. "Spartan Austerity." The Classical Quarterly 27: 111-126.

Hynek 2015: Hynek, B. 2015. Philosophy and Dietetics in the Hippocratic On Regimen: A Delicate Balance. Leiden-Boston: Brill. 
Jameson 1994: Jameson, M.H. 1994. "Theoxenia in Ancient Greek Cult Practice from the Epigraphical Evidence." Swedish Institute at Athens ActaAth-8o 13: 35-57.

Johnson 2013: Johnson, A. P. 2013. Religion and Identity in Porphyry of Tyre: The Limits of Hellenism in Late Antiquity. Cambridge: Cambridge University Press.

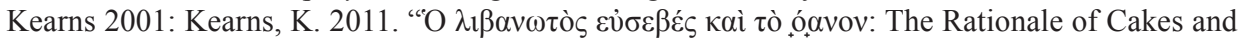
Bloodless Offerings in Greek Sacrifice.” Kernos Supplement 26: 89-103.

Krueger 1999: Krueger, D. 1999. "Hagiography as an Ascetic Practice in the Early Christian East." The Journal of Religion 79: 216-232.

Marx-Wolf 2010: Marx-Wolf, H. 2010. "High Priests of the Highest God: Third-Century Platonists as Ritual Experts." Journal of Early Christian Studies 18: 481-513.

Naiden 2013: Naiden, F. S. 2013. Smoke Signals for the Gods: Ancient Greek Sacrifice from the Archaic Through Roman Periods. Oxford: Oxford University Press.

Nilsson 1945: Nilsson, M. 1945. "Pagan divine service in late antiquity." Harvard Theological Review 65: 63-69.

Pritchard 2013: Pritchard, D. 2013. Sport, Democracy and War in Classical Athens. Cambridge: Cambridge University Press.

Purcell 2003: Purcell, N. 2003. "The Way We Used to Eat: Diet, Community and History at Rome." American Journal of Philology 124: 330-358.

Remijsen 2015: Remijsen, S. 2015. The End of Athletics in Late Antiquity. Greek Culture in the Roman World. Cambridge: Cambridge University Press.

Rivers 2003: Rives, J.B. 2003. "The Theology of Animal Sacrifice in the Ancient Greek World: Origins and Developments." In Ancient Mediterranean Sacrifice. Ed. by J.V. Knust and Z. Varhelyi, 187-202. Oxford and New York: Oxford University Press.

Totelin 2009: Totelin, L. 2009. Hippocratic Recipes: Oral and Written Transmission of Pharmacological Knowledge in Fifth- and Fourth-Century Greece. Leiden: Brill.

Townsend 2003: Townsend, P. 2003. "Bonds of Flesh and Blood: Porphyry, Animal Sacrifice and Empire.” In Ancient Mediterranean Sacrifice. Ed. by J.V. Knust and Z. Varhelyi, 214-231. Oxford and New York: Oxford University Press.

Vaage 1992: Vaage, L.E. 1992. "Like Dogs Barking: Cynic Parresia and Shameless Asceticism." Semeia 57: 25-39.

Zhmud 2012: Zhmud, L. 2012. Pythagoras and the Early Pythagoreans. Oxford: Oxford University Press.

\section{THE TRAINING OF PORPHYRY'S ‘ATHLETE': THE ASCETIC PHILOSOPHER IN ON THE ABSTINENCE FROM EATING FLESH}

\section{Sum mary}

The image of the athlete who enters the stadium, stripping his clothes, is revealed in Porphyry's On the Abstinence from Eating Flesh as a pertinent metaphor to describe the importance of the soul's removal of material bonds and eventual freedom from its lamentable misery of corporeal stagnation. In Porphyry's estimation, the traditionally acclaimed training of the historical Greek athlete is comparable to the specific training for the ultimate perfection of the ascetic philosopher's "Olympia of the soul." Porphyry informs his readers that it is, however, a different kind of training - a training which is in reality a lifestyle pattern embodying a severe physical exertion for limiting material concerns. He explains that while the masses seek ways to collect more and more material riches, the ascetic philosopher will find ways to reduce them. This search is metaphorically the ascetic philosopher's "contest." It is not the kind of contest known to the Greek athlete as it is a "contest" for "immortality." This "contest" is a broader commitment that involves to divest 
from not from one's clothing, as in the case of the historical athlete, but from commitment to sensory concerns. The specific "contest" prescribed for the ascetic philosopher involves strenuous labor which involves severe forms of mortification of the body such as frugality and immaterial sacrifice. Porphyry writes that these will assist him to reach his ultimate goal - the ascent to his rightful abode. The athletic motif is considered by Porphyry as a potential medium for representing the ascetic philosopher as undergoing the conceptual training for the "Olympia of the soul" and for competing in a conceptual "contest." The athletic motif is a medium in which adequate space persists for exposing the ascetic philosopher as a specific kind of athlete - an athlete whose objectives are far removed from the constraints of the historical athlete but one whose focus is explicitly driven to accomplish conceptual objectives. 